\title{
Alkaline Dehydration of Human Urine Collected in Source-Separated Sanitation Systems Using Magnesium Oxide
}

\author{
Prithvi Simha $^{1 *}$, Christopher Friedrich ${ }^{2}$, Dyllon Garth Randall ${ }^{3}$ and Björn Vinnerås ${ }^{1}$ \\ ${ }^{1}$ Department of Energy and Technology, Swedish University of Agricultural Sciences, Uppsala, Sweden, ${ }^{2}$ Department of \\ Sanitation, Water and Solid Waste for Development (SANDEC), Swiss Federal Institute of Aquatic Science and Technology \\ (EAWAG), Dübendorf, Switzerland, ${ }^{3}$ Civil Engineering Department and the Future Water Institute, University of Cape Town, Cape \\ Town, South Africa
}

OPEN ACCESS

Edited by:

Efthalia Chatzisymeon, University of Edinburgh,

United Kingdom

Reviewed by: Kangning Xu,

Beiijing Forestry University, China Elizabeth Tilley,

University of Malawi, Malawi

*Correspondence: Prithvi Simha

Prithvi.Simha@slu.se prithvi.simha@mespom.eu

Specialty section:

This article was submitted to Water and Wastewater Management, a section of the journal

Frontiers in Environmental Science

Received: 21 October 2020

Accepted: 14 December 2020

Published: 20 January 2021

Citation:

Simha $P$, Friedrich $C$, Randall $D G$ and Vinnerås $B$ (2021) Alkaline Dehydration of Human Urine Collected in SourceSeparated Sanitation Systems Using

Magnesium Oxide.

Front. Environ. Sci. 8:619901. doi: 10.3389/fenvs.2020.619901
Fresh human urine, after it is alkalized to prevent the enzymatic hydrolysis of urea, can be dehydrated to reduce its volume and to produce a solid fertilizer. In this study, we investigated the suitability of $\mathrm{MgO}$ to alkalize and dehydrate urine. We selected $\mathrm{MgO}$ due to its low solubility $\left(<2 \mathrm{~g} \cdot \mathrm{L}^{-1}\right)$ and relatively high saturation $\mathrm{pH}(9.9 \pm 0.2)$ in urine. Using a laboratory-scale setup, we dehydrated urine added to pure $\mathrm{MgO}$ and $\mathrm{MgO}$ mixed with co-substrates (biochar, wheat bran, or calcium hydroxide) at a temperature of $50^{\circ} \mathrm{C}$. We found that, dehydrating urine added to a mixture of $\mathrm{MgO}(25 \% \mathrm{w} / \mathrm{w})$, biochar, and wheat bran resulted in a mass reduction of $>90 \%$ and $\mathrm{N}$ recovery of $80 \%$, and yielded products with high concentrations of macronutrients $(7.8 \% \mathrm{~N}, 0.7 \% \mathrm{P}$ and $3.9 \% \mathrm{~K})$. By modeling the chemical speciation in urine, we also showed that ammonia stripping rather than urea hydrolysis limited the $\mathrm{N}$ recovery, since the urine used in our study was partially hydrolyzed. To maximize the recovery of $\mathrm{N}$ during alkaline urine dehydration using $\mathrm{MgO}$, we recommend treating fresh/un-hydrolysed urine a temperature $<40^{\circ} \mathrm{C}$, tailoring the drying substrate to capture $\mathrm{NH}_{4}^{+}$as struvite, and using co-substrates to limit the molecular diffusion of ammonia. Treating fresh urine by alkaline dehydration requires

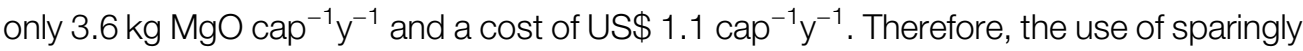
soluble alkaline compounds like $\mathrm{MgO}$ in urine-diverting sanitation systems holds much promise.

Keywords: ammonia, fertilizer, nitrogen recycling, urine source separation, wastewater, urine dehydration, sanitation, MgO

\section{INTRODUCTION}

In the decentralized sanitation sector, there is a growing body of research focusing on urine-diversion based systems that treat and recycle human urine as crop fertilizer (Larsen et al., 2013; Martin et al., 2020). Several promising technologies at various scales are being developed across the world for the on-site treatment of urine (Harder et al., 2019). One among these technologies is alkaline dehydration (Simha et al., 2020a; Simha et al., 2020b; Simha et al., 2020c), where urine is dried to produce a solid fertilizer with 10-30 times higher concentrations of plant nutrients than what is originally present in freshly excreted urine. The treatment involves alkalizing urine $(\mathrm{pH} \geq 10)$ to 
inhibit the enzyme-catalyzed hydrolytic degradation of urea (Krajewska, 2009). In freshly excreted urine, approximately $85 \%$ of the $\mathrm{N}$ is present as urea (Kirchmann and Pettersson, 1994), whereas in hydrolyzed urine, $\mathrm{N}$ is present as ammonia and ammonium instead (Chipako and Randall, 2020). Urease (urea amidohydrolase, EC 3.5.1.5), a nickel-containing metalloenzyme catalyses the hydrolysis of urea (Blakeley et al., 1982; Blakeley and Zerner, 1984). Urease-producing bacteria are widespread in the environment (Mobley and Hausinger, 1989), and are commonly found in urine-diverting sanitation systems (Udert et al., 2003). Therefore, the motivation to alkalize urine is to inhibit enzymatic ureolysis, as this allows evaporating water from urine and recovering $\mathrm{N}$ as urea, a widely used crop fertilizer (Dampney et al., 2003).

Several compounds (e.g., thiols, acetohydroxamic acid) can competitively inhibit urease activity (Krajewska, 2009). In previous studies, we have demonstrated that urease present in source-separated urine can be inhibited simply by increasing the $\mathrm{pH}$ of urine; according to Geinzer (2017), a pH above 10 is necessary for inactivation. To alkalize urine, wood ash (Dutta and Vinneras, 2016; Senecal and Vinneras, 2017; Senecal et al., 2018; Simha et al., 2018), $\mathrm{Ca}(\mathrm{OH})_{2}$ (Dutta and Vinneras, 2016; Randall et al., 2016; Simha et al., 2020a; Simha et al., 2020b), KOH (Simha et al., 2018) and anion-exchange resin (Simha et al., 2018) can be used as alkalizing agents. While all the aforementioned can increase the $\mathrm{pH}$ of fresh urine, not all are equally effective as alkaline substrates for dehydrating urine. Here, effectiveness refers to the volume of urine that can be treated by a unit mass of a substrate under a given set of drying conditions. When urine that is added to an alkaline substrate is dried convectively, its $\mathrm{pH}$ gradually decreases, primarily due to the absorption of $\mathrm{CO}_{2}$ which produces $\mathrm{HCO}_{3}^{-}$and $\mathrm{CO}_{3}^{2-}$ ions (Simha et al., 2018). Since there can be reactivation of urease at $\mathrm{pH}<10$, on reaching this threshold, no further urine addition to the substrate can take place without subsequently losing $\mathrm{N}$ as $\mathrm{NH}_{3}$.

In this regard, there can be many advantages to using sparingly soluble alkaline earth metal compounds [e.g., $\mathrm{Ca}(\mathrm{OH})_{2}$ or $\mathrm{Mg}$ $(\mathrm{OH})_{2}$ ] as substrates for alkaline urine dehydration. First, because of their low solubility, urine can be dosed passively, meaning the compounds would dissolve as needed depending on the volume of urine added (Flanagan and Randall, 2018). Secondly, urine can be easily saturated with these compounds to attain saturation $\mathrm{pH}$ values that do not significantly differ for different urine compositions (Randall et al., 2016). Thirdly, the $\mathrm{pH}$ does not vary when urine is dosed in excess of that required for achieving saturation (Randall et al., 2016; Simha et al., 2020b); this is in contrast to alkalizing urine with alkali metal hydroxides (e.g., $\mathrm{KOH}$ ), where the volume of urine determines dosage and subsequently, the $\mathrm{pH}$.

Past studies have demonstrated that $\mathrm{Ca}(\mathrm{OH})_{2}$ is an effective substrate for alkalising (Randall et al., 2016; Flanagan and Randall, 2018) and dehydrating (Dutta and Vinneras, 2016; Simha et al., 2020b) urine. In this study, we wanted to investigate whether magnesium oxide $(\mathrm{MgO})$ could be used instead for treating urine by alkaline dehydration. The motivation for investigating this was two-fold. On hydration, $\mathrm{MgO}$ produces $\mathrm{Mg}(\mathrm{OH})_{2}$ according to the following reaction (Rocha et al., 2004):

$$
\mathrm{MgO}_{(\mathrm{s})}+\mathrm{H}_{2} \mathrm{O}_{(\mathrm{l})} \rightarrow \mathrm{Mg}_{(\mathrm{aq})}^{2+}+2 \mathrm{OH}_{(\mathrm{aq})}^{-} .
$$

When sufficient $\mathrm{MgO}$ is added to urine, it creates a saturated solution and increases the urine $\mathrm{pH}$ to $9.9 \pm 0.2$ (Simha et al., in preparation). The increase in $\mathrm{pH}$ could be sufficient for inhibiting enzymatic urea hydrolysis but has the co-benefit of minimizing the potential loss of urea to chemical hydrolysis, which is strongly $\mathrm{pH}$ dependent (Blakeley et al., 1982). The solubility of $\mathrm{MgO}$ in fresh urine at $25^{\circ} \mathrm{C}$ is $<1.5 \mathrm{~g} \cdot \mathrm{L}^{-1}$ (Simha et al., in preparation), much lower than the solubility of $\mathrm{Ca}(\mathrm{OH})_{2}$, which according to Randall et al. (2016) varies between 3.5 and $5 \mathrm{~g} \cdot \mathrm{L}^{-1}$, since it depends on the urine composition.

$\mathrm{MgO}$ has been used previously by others for treating urine, especially for recovering $\mathrm{P}$ by precipitating struvite from hydrolyzed urine (Ganrot et al., 2007; Wilsenach et al., 2007). However, in this treatment chain, because of poor capture of $\mathrm{N}$ and $\mathrm{K}$, only about $20 \%$ of the monetary value of urine as fertilizer can be recovered (Etter et al., 2011). To the best of our knowledge, $\mathrm{MgO}$ has not been used to treat urine by alkaline dehydration. Hence, the overall objective of this study was to investigate the alkaline dehydration of urine when added to $\mathrm{MgO}$. The aim was to treat approximately $20 \mathrm{~L}$ urine $\mathrm{d}^{-1} \mathrm{~m}^{-2}$ using pure $\mathrm{MgO}$ or $\mathrm{MgO}$ mixed with the following co-substrates-biochar, wheat bran, or $\mathrm{Ca}(\mathrm{OH})_{2}$. The co-substrates biochar and bran were added to break up peptide films that usually form over the surface of urine and limit the evaporative removal of water (Tettenborn et al., 2007). Specifically, we investigated the 1) recovery of N;2) changes in the physical and chemical properties of the drying substrate; and, 3) the elemental composition of the end-products. In addition, by modeling the chemical speciation, we provided insights into the solubility and saturation $\mathrm{pH}$ of $\mathrm{MgO}$ added to human urine.

\section{METHODOLOGY}

\section{Materials}

\section{Urine}

Around 20 volunteers (male and female, aged 25-65 years) anonymously donated urine in $500 \mathrm{ml}$ sterile high-density polyethylene bottles at different times of the day. The filled bottles were collected at the end of the working day $(<12 \mathrm{~h})$ and refrigerated at $3^{\circ} \mathrm{C}\left( \pm 1^{\circ} \mathrm{C}\right)$ for $<14$ days. When it was needed, urine was removed from the fridge, mixed in a $5 \mathrm{~L}$ Florence flask, heated using a water bath to $37 \pm 1^{\circ} \mathrm{C}$ (to simulate its temperature at excretion), and used in the drying experiments.

\section{Alkaline substrate}

Laboratory grade $\mathrm{MgO}$ (Acros Organics, Belgium) was used in powder form $\left(d_{99}<150 \mu \mathrm{m}\right)$. Food grade wheat bran (Kungsörnen, Sweden), technical grade $\mathrm{Ca}(\mathrm{OH})_{2}$ (Nordkalk Corporation, Sweden) and non-activated biochar (Vindelkol $\mathrm{AB}$, Sweden; particle $\varnothing<1 \mathrm{~mm}$ ) were used without any pretreatment.

Five different alkaline substrates were evaluated through an exploratory approach (Table 1). In all substrates, the content of $\mathrm{MgO}$ was in excess to that required for saturating approximately 
TABLE 1 | Mass composition (as \% of total mass) of the five drying substrates used in this study. The total mass of each substrate was $30 \mathrm{~g}$.

\begin{tabular}{lccc}
\hline Drying substrate & Magnesium oxide (MgO) & Biochar (Bc) & Wheat bran (Br) \\
\hline $\mathrm{MgO}$ & 100 & - & - \\
$\mathrm{MgO}-\mathrm{Bc}$ & 25 & 75 & - \\
$\mathrm{MgO}-\mathrm{Bc}-\mathrm{Br}$ & 25 & 37.5 & 37.5 \\
$\mathrm{MgO}-\mathrm{Bc}-\mathrm{Lime}$ & 11.7 & 66.7 & - \\
$\mathrm{MgO}-\mathrm{Bc}-\mathrm{Br}-\mathrm{Lime}$ & 11.7 & 33.3 & - \\
\end{tabular}

$1 \mathrm{~L}$ of fresh urine. The co-substrates were pure biochar and a mixture of biochar and wheat bran. Both the co-substrates were tested with and without addition of $\mathrm{Ca}(\mathrm{OH})_{2}$. This was done to assess the effect of high $\mathrm{pH}(>12)$ at the start of the treatment on the recovery of $\mathrm{N}$ from urine.

\section{Experiment}

The study was performed in a modified benchtop incubator that was used in Simha et al. (2020b). Briefly, the setup consisted of four air pumps (Rena 301, Rena Aquatic Supply, United States) which introduced air at the rate of $5 \mathrm{~L} \cdot \mathrm{min}^{-1}$ while eight computer fans (Spire Corp, Netherlands) redistributed the air inside the incubator cavity. The incubator had two stainless steel grates over which square polystyrene Petri dishes (Sarstedt, Germany; dimensions $100 \mathrm{~mm} \times 100 \mathrm{~mm} \times 20 \mathrm{~mm}$ ) were placed. The temperature of the incubator was set to have an average drying temperature of $50^{\circ} \mathrm{C}$. There were two reasons for selecting this drying temperature. First, we wanted to minimize the possibility of losing urea- $\mathrm{N}$ to chemical hydrolysis, which increases rapidly above $50^{\circ} \mathrm{C}$ (Blakeley et al., 1982). Secondly, we wanted to have high dehydration rates, and a previous experiment demonstrated that up to $20 \mathrm{~L}$ of urine could be dried per day per square meter at this temperature (Simha et al., 2020b).

At the start of the experiment, the Petri dishes contained $30 \mathrm{~g}$ triplicates of the five alkaline substrates. To each Petri dish, preheated urine $\left(37 \pm 2^{\circ} \mathrm{C}\right)$ was added and dried at $50^{\circ} \mathrm{C}$ for a fixed duration of time. Then, the Petri dishes were withdrawn from the incubator, marking the end of what we called a drying cycle. In the first drying cycle, $90 \mathrm{ml}$ of urine was added to prevent air suspension of the substrate; in the rest of the cycles, $30 \mathrm{ml}$ of urine was added. Based on results obtained in Simha et al. (2020b), the drying time was fixed at $7 \mathrm{~min} \cdot \mathrm{ml}^{-1}$ urine. However, the incubator was operated for an additional hour if it was observed that urine pooled over surface of the substrate; there were five such prolonged drying cycles. In total, there were 35 drying cycles and the total drying time was 5.6 days, with each Petri dish treating $1.11 \mathrm{~L}$ of urine. We performed the drying treatment in cycles in order to represent real-life implementation, where the surface area available for drying urine inside bathrooms is usually small and drying would have to be performed after every urination event.

\section{Chemical and Physical Analyses}

At the end of every working day, $10 \mathrm{ml}$ aliquots of the urine used in the experiments was sampled and refrigerated at $-20^{\circ} \mathrm{C}$. At the end of the experiment, the urine was thawed, pooled and analyzed for $\mathrm{pH}$, electrical conductivity (EC), Total Solids (TS), Volatile Solids (VS), total $\mathrm{N}$, total $\mathrm{P}$ and $\mathrm{NH}_{4}-\mathrm{N}$. The $\mathrm{pH}$ was measured using a combination electrode coupled to a PHM210 meter (Radiometer Analytical, France). EC was measured using a handheld multimeter (Cond 340i, WTW, Germany) and a TetraCon 325 probe (WTW, Germany). Urine samples were dried at $110^{\circ} \mathrm{C}$ for $14 \mathrm{~h}$ for determining $\mathrm{TS}$ and then combusted at $550^{\circ} \mathrm{C}$ for $6 \mathrm{~h}$ for determining VS. The TS content of urine was adjusted to account for the loss of urea due to heat degradation. The urea concentration was calculated by estimating urea- $\mathrm{N}$ to be $70 \%$ of the total $\mathrm{N}$ in urine, since the $\mathrm{NH}_{4}-\mathrm{N}$ concentration was $1.7 \mathrm{~g} \cdot \mathrm{L}^{-1}$.

Spectroquant ${ }^{\circledR}$ test kits (Merck KGaA, Germany) were used according to manufacturer instructions to measure $\mathrm{NH}_{4}-\mathrm{N}$ (test kit 100683; measurement range $5-150 \mathrm{mg} \cdot \mathrm{L}^{-1}$ ), total $\mathrm{N}$ (test kit 109713; measurement range $0.1-25 \mathrm{mg} \cdot \mathrm{L}^{-1}$ ), and total $\mathrm{P}$ (test kit 114848; measurement range $0.05-5.0 \mathrm{mg} \cdot \mathrm{L}^{-1}$ ). For this analysis, urine was diluted with deionized water and then digested using either Spectroquant ${ }^{\circledR}$ Crack-Set 10 (for total P) or Crack-Set 20 (for total N). Colorimetric readings were taken with a photometer (NOVA 60 A Spectroquant ${ }^{\circledR}$, Merck KGaA, Germany).

The alkaline substrate was characterized, before and after urine dehydration for $\mathrm{pH}, \mathrm{EC}, \mathrm{TS}, \mathrm{VS}$ and elemental composition ( $\mathrm{N}, \mathrm{P}, \mathrm{K}, \mathrm{C}$ and $\mathrm{S})$. The $\mathrm{pH}$ and $\mathrm{EC}$ were measured for 1:5 (w/v) substrate: urine suspensions at room temperature $\left(21 \pm 2^{\circ} \mathrm{C}\right)$ after a resting time of $1 \mathrm{~h}$. The $\mathrm{N}$ and $\mathrm{C}$ content was determined using an elemental analyser (LECO TruMac ${ }^{\circledR}$ CN, United States) while the P, K, and S content was measured by optical emission spectrometry (Optima Avio 200, PerkinElmer, United States).

\section{Calculations}

To evaluate the effectiveness of the substrates to reduce the mass of urine, on wet basis (WB) we calculated the \% mass reduction ( mass.red $_{W B}$; Eq. 1), mass concentration factor ( mass.cf $_{W B}$; Eq. 2) and the average dehydration rate $\left(\overline{\text { dry.rate }}_{W B} ;\right.$ Eq. 3) (Simha et al., $2020 b)$. In these equations, $m_{\text {substrate }}, m_{\text {urine }}$, and $m_{\text {end-product }}$ are the weight of the drying substrate at the start of the experiment, the total urine added in the experiment, and the end-product, respectively; $w_{i}$ and $w_{i+1}$ are the weight of the Petri dish measured after fresh urine was added to the substrate, and after the urine had dried in the incubator; $t$ is the dehydration time (h) and $A$ is the surface area $\left(\mathrm{m}^{2}\right)$.

$$
\text { mass.red }_{W B}=\left(\frac{m_{\text {substrate }}+m_{\text {urine }}-m_{\text {end-product }}}{m_{\text {substrate }}+m_{\text {urine }}}\right) \times 100 \text {, }
$$




$$
\begin{aligned}
& \text { mass. } c f_{W B}=\left(\frac{m_{\text {substrate }}+m_{\text {urine }}}{m_{\text {end-product }}}\right) \text {, } \\
& \overline{\text { dry.rate }}_{W B}=\frac{1}{n} \sum_{i=1}^{n}\left(\frac{w_{i}-w_{i+1}}{t \times A}\right) \times 100 \text {, }
\end{aligned}
$$

A mass balance was carried out to calculate the experimental recovery of total $\mathrm{N}$ from urine. This was then compared against the potential recovery of urea- $\mathrm{N}$ when drying urine at the incubator's average recorded temperature $\left(48.1 \pm 1.5^{\circ} \mathrm{C}\right)$. At this temperature, the half-life of urea was calculated to be 133 days using the equation described in Simha et al. (2020b). We assumed that $\mathrm{N}$ in urine is present only as urea and $\mathrm{NH}_{4}{ }^{+}$and approximated the urea- $\mathrm{N}$ concentration in urine as $70 \%$ of the total $\mathrm{N}$ measured by the experiment $\left(5.7 \pm 0.1 \mathrm{~g} \cdot \mathrm{L}^{-1}\right)$ since the $\mathrm{NH}_{4}-\mathrm{N}$ concentration was $1.7 \mathrm{~g} \cdot \mathrm{L}^{-1}$.

\section{Statistical Analysis}

The Shapiro-Wilk test was used to verify data normality and the Brown-Forsythe-Levene test was used to verify equal variance between the data for the different drying substrates. To identify significant differences between the substrates, at 95\% confidence interval, analysis of variance (ANOVA) followed by Tukey's multiple comparison test (Honest Significant Difference, HSD) was performed. Additionally, unpaired two-sample Student's $t$-test was performed to compare the physicochemical properties of the substrates at the start and at the end of the treatment. All the statistical analyses were performed using RStudio version 1.2.5042 and R version 4.0.0 (RStudio Team, 2016). The R-packages car (Fox and Weisberg, 2018) and agricolae (de Mendiburu, 2020) were used for these analyses.

\section{Modeling Chemical Speciation}

The composition shown in Table 2 was used to calculate the chemical speciation at different conditions using OLI Stream Analyzer (OLI Systems Inc., 2020) and the Mixed Solvent Electrolyte (MSE) model option of the software. These simulations were run to understand the solubility of $\mathrm{MgO}$ in urine, the saturation $\mathrm{pH}$ of urine, as well as the effect of temperature on both parameters. We also modeled the urine with a reduced ammonia $\mathrm{N}$ concentration $\left(400 \mathrm{mg} \cdot \mathrm{L}^{-1}\right)$ as against the composition measured in this study, $1,700 \mathrm{mg} \cdot \mathrm{L}^{-1}$, to understand the effect ammonia $\mathrm{N}$ has on the solubility of $\mathrm{MgO}$. The results were used to develop speciation curves for ammonia $\mathrm{N}$ in urine at different $\mathrm{pH}$ values, temperatures, and water content (as the treatment involves dehydration of urine). For this simulation, we used $\mathrm{MgO} / \mathrm{Ca}(\mathrm{OH})_{2}$ to increase the $\mathrm{pH}$ of urine and acid $(\mathrm{HCl})$ to decrease its $\mathrm{pH}$ so as to have a range from 6 to 13 .

\section{RESULTS}

\section{Mass Balance}

Treating urine by alkaline dehydration reduced its mass by $>90 \%$ in all the substrates. Pure $\mathrm{MgO}$ was the most efficient in terms of reducing the mass of urine; the mass concentration factor
TABLE 2 | Composition of the urine used in the study for modeling the chemical speciation.

\begin{tabular}{lcc}
\hline Measurement & Unit & Value \\
\hline Urea-N & $\mathrm{g} \mathrm{m}^{-3}$ & $4,033^{\mathrm{a}}$ \\
$\mathrm{PO}_{4}-\mathrm{P}$ & $\mathrm{g} \mathrm{m}^{-3}$ & $610^{\mathrm{b}}$ \\
Total-N & $\mathrm{g} \mathrm{m}^{-3}$ & $5,733^{\mathrm{b}}$ \\
Total ammonia-N & $\mathrm{g} \mathrm{m}^{-3}$ & $1,700^{\mathrm{b}}$ \\
$\mathrm{Cl}^{-}$ & $\mathrm{g} \mathrm{m}^{-3}$ & $2,600^{\mathrm{c}}$ \\
$\mathrm{SO}_{4}^{2-}$ & $\mathrm{g} \mathrm{m}^{-3}$ & $968^{\mathrm{d}}$ \\
$\mathrm{Na}^{+}$ & $\mathrm{g} \mathrm{m}^{-3}$ & $1,684^{\mathrm{d}}$ \\
$\mathrm{K}^{+}$ & $\mathrm{g} \mathrm{m}^{-3}$ & $1,911^{\mathrm{d}}$ \\
$\mathrm{Ca}^{2+}$ & $\mathrm{g} \mathrm{m}^{-3}$ & $84^{\mathrm{d}}$ \\
$\mathrm{Mg}^{2+}$ & $\mathrm{g} \mathrm{m}^{-3}$ & $54^{\mathrm{d}}$ \\
$\mathrm{pH}^{2+}$ & - & $6.64^{\mathrm{d}}$
\end{tabular}

${ }^{a}$ Estimated to be $70 \%$ of the measured total $N$.

${ }^{b}$ Measured using Spectroquant ${ }^{\circledR}$ test kits.

'Simulated value.

${ }^{d}$ Calculated from mass balance.

reduced with addition of co-substrates (Table 3 ). The endproduct obtained by drying urine in pure $\mathrm{MgO}$ weighed the least (14 times less) and was significantly different $(p<0.001)$ than the rest. The average dehydration rate varied between $19.1 \pm 4.3$ (for $\mathrm{MgO}-\mathrm{Bc}$ ) and $19.7 \pm 4.5 \mathrm{~kg} \cdot \mathrm{m}^{-2} \mathrm{~d}^{-1}$ (for pure $\mathrm{MgO})$, although there was no significant difference $(p<0.05)$ between the substrates.

A mass balance was carried out to estimate the recovery of $\mathrm{N}$ from urine after the dehydration treatment (Supplementary Figure S1). The least N recovery (only 67\%) was observed for urine treated using pure $\mathrm{MgO}$. However, the recovery improved in the presence of co-substrates (Table 3 ). The recovery was highest when urine was dehydrated in $\mathrm{MgO}$ $(25 \% \mathrm{w} / \mathrm{w})$ mixed with equal parts biochar and wheat bran. Furthermore, the addition of $\mathrm{Ca}(\mathrm{OH})_{2}$ to the substrate resulted in lower $\mathrm{N}$ recovery although the difference was not always significant.

Treating urine by dehydration at $50^{\circ} \mathrm{C}$ and $\mathrm{pH}$ of approximately 10 resulted in $>20 \%$ loss of $\mathrm{N}$. Of the total $\mathrm{N}$ present in urine, approximately $70 \%$ was present in the form of urea-N (Methodology section). Following Warner (1942), under the treatment conditions, the potential loss of urea- $\mathrm{N}$ to chemical hydrolysis was only $1.2 \%$. Therefore, the loss of $\mathrm{N}$ was due to other mechanisms.

\section{End-Product Composition}

On a TS basis, drying urine in pure $\mathrm{MgO}$ yielded end-products containing $6.5 \% \mathrm{~N}, 0.5 \% \mathrm{P}$, and $3.3 \% \mathrm{~K}$. Adding co-substrates to $\mathrm{MgO}$ improved its NPK content (Table 4). The most concentrated NPK product was obtained when the substrate contained biochar as well as wheat bran; on average, it had $7.8 \% \mathrm{~N}, 0.7 \% \mathrm{P}$ and $3.9 \% \mathrm{~K}$. The presence of $\mathrm{Ca}(\mathrm{OH})_{2}$ did not significantly alter this composition $(p<0.05)$. The $\mathrm{C}$ content of urine dried in pure $\mathrm{MgO}$ was only $6.8 \%$ but was as high as $31 \%$ for $\mathrm{MgO}-\mathrm{Bc}$. The end-product $\mathrm{C}$ content depended on the amount of biochar or wheat bran initially added to the substrate. All the end-products also contained $0.6 \% \mathrm{~S}$. 


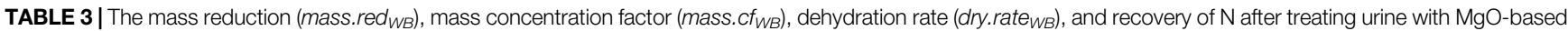
drying substrates

\begin{tabular}{|c|c|c|c|c|}
\hline Drying substrate & mass.red $_{W B}(\%)$ & mass.cf ${ }_{W B}(-)$ & dry.rate $_{W B}\left(\mathrm{~kg} \cdot \mathrm{day}^{-1} \cdot \mathrm{m}^{-2}\right)$ & $\mathrm{N}$ recovery $(\%)$ \\
\hline $\mathrm{MgO}$ & $92.9(0.1)^{\mathrm{a}}$ & $14.1(0.2)^{\mathrm{a}}$ & $19.7(4.5)$ & $66.8(1.2)^{d}$ \\
\hline $\mathrm{MgO}-\mathrm{Bc}$ & $90.5(0.3)^{b}$ & $10.6(0.4)^{b}$ & 19.1 (4.3) & $75.5(0.4)^{b c}$ \\
\hline $\mathrm{MgO}-\mathrm{Bc}-\mathrm{Br}$ & $90.6(0.5)^{b}$ & $10.7(0.6)^{b}$ & $19.2(4.6)$ & $79.7(1.1)^{\mathrm{a}}$ \\
\hline MgO-Bc-Lime & $90.5(0.2)^{b}$ & $10.6(0.2)^{b}$ & $19.2(4.7)$ & $74.5(0.9)^{c}$ \\
\hline MgO-Bc-Br-Lime & $90.5(0.4)^{\mathrm{b}}$ & $10.5(0.6)^{b}$ & $19.5(5.0)$ & $77.6(0.7)^{\mathrm{ab}}$ \\
\hline
\end{tabular}

Values are mean (standard deviation) $(\mathrm{n}=3)$. Within columns, different letters indicate significant difference $(\alpha=0.05)$.

TABLE 4 | The elemental composition (as \% of TS) of the drying substrate at the start and at the end, after dehydrating urine for 5.6 days

\begin{tabular}{|c|c|c|c|c|c|c|c|c|c|c|}
\hline \multirow[t]{2}{*}{ Drying substrate } & \multicolumn{2}{|c|}{$\mathbf{N}$} & \multicolumn{2}{|r|}{$\mathbf{P}$} & \multicolumn{2}{|c|}{$\mathbf{K}$} & \multicolumn{2}{|c|}{ C } & \multicolumn{2}{|c|}{$\mathbf{S}$} \\
\hline & Start & End & Start & End & Start & End & Start & End & Start & End \\
\hline $\mathrm{MgO}$ & $0^{d}$ & $6.5^{c}$ & $0^{c}$ & $0.5 \pm 0.03^{c}$ & $0^{d}$ & $3.3 \pm 0.22^{b}$ & $0^{e}$ & $6.8^{d}$ & $0^{b}$ & $0.6 \pm 0.14^{a}$ \\
\hline $\mathrm{MgO}-\mathrm{Bc}$ & $0.07^{\mathrm{c}}$ & $7.4^{b}$ & $0.01^{\mathrm{c}}$ & $0.6^{\mathrm{b}}$ & $0.09 \pm 0.01^{c}$ & $3.8^{\mathrm{a}}$ & $54.2^{\mathrm{a}}$ & $30.9^{a}$ & $0.01 \pm 0.007^{b}$ & $0.6^{\mathrm{a}}$ \\
\hline $\mathrm{MgO}-\mathrm{Bc}-\mathrm{Br}$ & $1.01^{\mathrm{a}}$ & $7.8^{\mathrm{a}}$ & $0.38^{\mathrm{a}}$ & $0.7^{\mathrm{a}}$ & $0.49^{a}$ & $3.8 \pm 0.21^{a}$ & $43.5^{\mathrm{c}}$ & $27.7^{\mathrm{b}}$ & $0.06^{a}$ & $0.6^{a}$ \\
\hline MgO-Bc-Lime & $0.07^{\mathrm{c}}$ & $7.4^{\mathrm{b}}$ & $0.01^{c}$ & $0.6^{b}$ & $0.08 \pm 0.01^{c}$ & $3.7^{\mathrm{ab}}$ & $48.2^{b}$ & $29.8^{a}$ & $0.01 \pm 0.006^{b}$ & $0.6^{\mathrm{a}}$ \\
\hline MgO-Bc-Br-Lime & $0.9^{b}$ & $7.8^{\mathrm{a}}$ & $0.3^{\mathrm{b}}$ & $0.7^{\mathrm{a}}$ & $0.4^{\mathrm{b}}$ & $3.9 \pm 0.23^{a}$ & $38.6^{d}$ & $24.8^{c}$ & $0.05^{a}$ & $0.6 \pm 0.04^{a}$ \\
\hline
\end{tabular}

Mean \pm standard deviation $(\mathrm{n}=3$ ). For initial composition, deviations $<10 \%$ are not presented. For end composition, deviations $<5 \%$ are not presented. Within columns, different letters indicate significant difference ( $\alpha=0.05)$.

TABLE $5 \mid \mathrm{pH}$ and $\mathrm{EC}$ of the substrates at the start and at the end of the dehydration treatment measured in 1:5 (w/v) substrate: urine suspensions at room temperature $\left(21 \pm 2^{\circ} \mathrm{C}\right)$.

\begin{tabular}{|c|c|c|c|c|}
\hline \multirow[t]{2}{*}{ Drying substrate } & \multicolumn{2}{|c|}{$\mathrm{pH}_{1: 5}(-)$} & \multicolumn{2}{|c|}{$\mathrm{EC}_{1: 5}\left(\mathrm{mS} \mathrm{cm}^{-1}\right)$} \\
\hline & Start ${ }^{a}$ & End $^{b}$ & Start ${ }^{a}$ & End $^{b}$ \\
\hline $\mathrm{MgO}$ & $10.3^{c}$ & $10.1^{\mathrm{a}, \star \star \star}$ & $9.2^{\mathrm{ab}}$ & $29.7^{a, \star \star \star}$ \\
\hline $\mathrm{MgO}-\mathrm{Bc}$ & $10.2^{c}$ & $9.9^{\mathrm{a}, \star \star}$ & $8.7^{\mathrm{ab}}$ & $25.4^{b, \star \star \star}$ \\
\hline $\mathrm{MgO}-\mathrm{Bc}-\mathrm{Br}$ & $9.8^{d}$ & $9.9^{a, \star \star}$ & $6.6 \pm 1.2^{b}$ & $25.8^{\mathrm{b}, \star \star \star}$ \\
\hline MgO-Bc-Lime & $12.7^{\mathrm{a}}$ & $10 \pm 0.1^{a, \star \star \star}$ & $12.8 \pm 3.9^{a}$ & $25.2^{\mathrm{b}, \star \star}$ \\
\hline $\mathrm{MgO}-\mathrm{Bc}-\mathrm{Br}$-Lime & $12.6^{b}$ & $10 \pm 0.3^{a, \star \star \star}$ & $13.1 \pm 2.9^{a}$ & $25.4^{\mathrm{b}, \star \star}$ \\
\hline
\end{tabular}

Mean \pm standard deviation $(\mathrm{n}=3$ ). Deviations $<5 \%$ are not presented. Within columns values marked with the same letter indicate no significant difference $(\alpha=0.05)$. For each substrate, values significantly different at the end of the treatment are shown as ${ }^{*} p<0.05$; ${ }^{* *} \mathrm{p}<0.01 ;{ }^{* * *} \mathrm{p}<0.001$.

aUrine used for the analysis had a $\mathrm{pH}$ of 6.7 and an EC of $9.4 \mathrm{mS} \cdot \mathrm{cm}^{-1}$.

${ }^{b}$ Urine used for the analysis had a $\mathrm{pH}$ of 6.9 and an EC of $10.1 \mathrm{mS} \cdot \mathrm{cm}^{-1}$

\section{Physicochemical Properties}

At the start of the treatment, at room temperature $\left(21 \pm 2^{\circ} \mathrm{C}\right)$, all the substrates were alkaline $(\mathrm{pH} \geq 9.8)$. The substrates with only $\mathrm{MgO}$ as the alkalizing agent had a $\mathrm{pH}$ of about 10 , reflecting the $\mathrm{pH}$ of urine saturated with $\mathrm{MgO} / \mathrm{Mg}(\mathrm{OH})_{2}$ (Simha et al., in preparation). Likewise, the initial $\mathrm{pH}$ of the substrates containing $\mathrm{Ca}(\mathrm{OH})_{2}$ was $>12.5$, which is the saturation $\mathrm{pH}$ of urine alkalized with $>5 \mathrm{~g} \mathrm{Ca}(\mathrm{OH})_{2} \mathrm{~L}^{-1}$ (Randall et al., 2016).

Following treatment, the $\mathrm{pH}$ of all the substrates significantly decreased, especially in the substrates that initially contained $\mathrm{Ca}$ $(\mathrm{OH})_{2}$. Yet, there was no significant difference $(p>0.05)$ between the different substrates since their average $\mathrm{pH}$ was around 10 (Table 5). All the substrates apart from pure $\mathrm{MgO}$ had similar EC, approximately $25 \mathrm{mS} \cdot \mathrm{cm}^{-1}$ when measured as 1:5 (substrate: urine) suspensions. Compared to the initial EC, the endproducts had higher EC because of accumulation of urine salts
[Simha et al. (2020a) for more information on the salt content of dried urine fertilizer]. The EC of the urine added to the treatment was $11.7 \pm 1.2 \mathrm{mS} \cdot \mathrm{cm}^{-1}$.

\section{DISCUSSION}

\section{Factors Affecting the Recovery of Nitrogen}

The initial ammonia $\mathrm{N}$ concentration of the urine used in the experiment was $30 \%$ of its total $\mathrm{N}$ concentration, and considerably higher than what is expected in fresh urine $(<5 \%)$. This indicated that urea was partially hydrolyzed during the storage of urine and before it was used in the drying treatment. When the partially hydrolyzed urine was treated by alkaline dehydration, between 20 and $33 \%$ of the $\mathrm{N}$ was lost, depending on the type of the alkaline substrate. Drying urine at $50^{\circ} \mathrm{C}$ using pure $\mathrm{MgO}$ recovered $67 \%$ of the $\mathrm{N}$. At the same drying temperature, Simha et al. (2020b) reported a $\mathrm{N}$ recovery of $78 \%$ when drying fresh human urine with initial ammonia concentration of $590 \mathrm{mg} \cdot \mathrm{L}^{-1}$ using pure $\mathrm{Ca}(\mathrm{OH})_{2}$. The $\mathrm{N}$ recovery of $\mathrm{MgO}$ improved with the addition of co-substrates; the recovery was maximum when $\mathrm{MgO}$ was mixed with both biochar and wheat bran (Table 2). Substituting $\mathrm{MgO}$ with $\mathrm{Ca}$ $(\mathrm{OH})_{2}$ resulted in a higher saturation $\mathrm{pH}$ but lowered the $\mathrm{N}$ recovery, although the differences were insignificant $(p<0.05)$.

The potential loss of urea- $\mathrm{N}(70 \%$ of the total $\mathrm{N})$ due to chemical hydrolysis was calculated to be just $1.2 \%$. The average $\mathrm{pH}$ of the substrates collected at the end of the experiment was $10 \pm 0.2$ (measured at $21 \pm 2^{\circ} \mathrm{C}$ ), indicating they were still strongly alkaline and thus, should have inhibited enzymatic ureolysis. However, both the solubility and the $\mathrm{pH}$ of the alkalizing agents used in this study were influenced by temperature (Figures (A,B). At $50^{\circ} \mathrm{C}$, the saturation $\mathrm{pH}$ of urine added to $\mathrm{MgO}$ was 

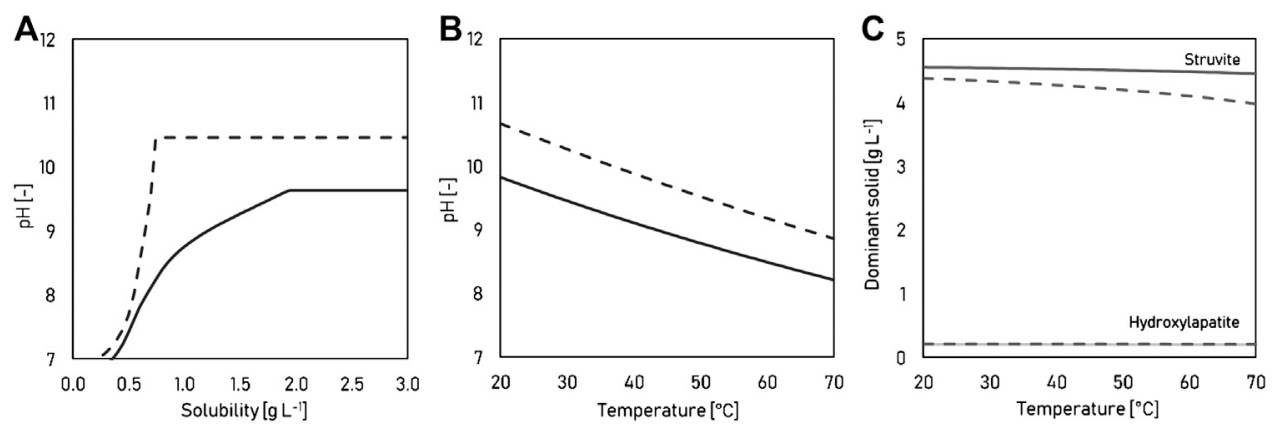

FIGURE 1 | Plots show the simulated (A) $\mathrm{pH}$ of urine vs. the solubility of $\mathrm{MgO}$ at $25^{\circ} \mathrm{C}$; (B) $\mathrm{pH}$ of urine saturated with $\mathrm{MgO}$ vs. temperature; and (C) dominant solids (struvite and hydroxylapatite) formed in saturated urine at different temperatures. Solid line represents the urine composition of this study (Table 1), while dashed line represents the same but with $\mathrm{NH}_{4}^{+}$concentration reduced to $400 \mathrm{mg} \cdot \mathrm{L}^{-1}$.

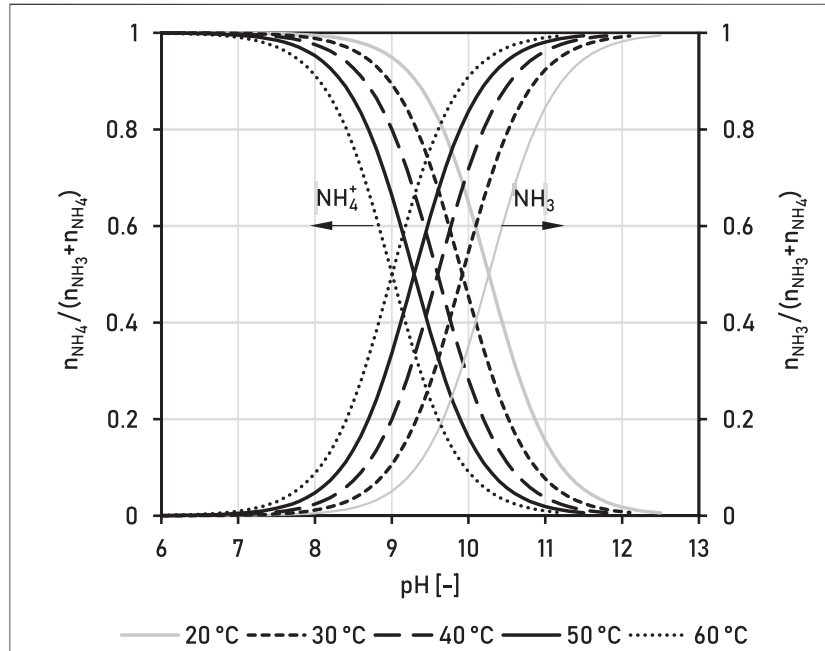

FIGURE 2 | Effect of temperature and $\mathrm{pH}$ on the distribution of $\mathrm{NH}_{4}^{+}$and $\mathrm{NH}_{3}$ in human urine.

only 8.8 (Figure 1B). It is unclear how the reduced $\mathrm{pH}$ in combination with the high EC of the substrates affected the urease enzyme activity. The high ammonia concentration in the urine used in this study (Table 2) indicated the presence of urease enzymes. Yet, the end-products recovered $>70 \% \mathrm{~N}$ suggesting that the enzyme activity was inhibited to some extent. Further studies are required to fully understand the enzymatic activity in such treatment conditions.

The most plausible explanation for the high $\mathrm{N}$ loss is ammonia stripping (Huang and Shang, 2006; Başakçilardan-Kabakci et al., 2007). In urine, ammonia nitrogen exists as both free ammonia/ dissolved gas $\left(\mathrm{NH}_{3}\right)$ and ammonium $\left(\mathrm{NH}_{4}^{+}\right)$according to an equilibrium that strongly depends on $\mathrm{pH}$ and temperature (Figure 2). However, the $\mathrm{NH}_{3}-\mathrm{NH}_{4}$ speciation is insignificantly affected by increasing ionic strength that occurs when urine is concentrated during dehydration. In fresh urine $(\mathrm{pH}<7)$, prior to treatment, almost all the ammonia $\mathrm{N}$ exists as $\mathrm{NH}_{4}^{+}$. However, during the treatment, when the $\mathrm{pH}$ of urine increased to $>10$ and the temperature increased to $50^{\circ} \mathrm{C},>80 \%$ of the ammonia $\mathrm{N}$ was present as $\mathrm{NH}_{3}$ (Figure 2). Since the drying surface area was the same for all the Petri dishes, interfacial $\mathrm{NH}_{3(\mathrm{~g})}$ transfer due to ventilation could have resulted in the high $\mathrm{N}$ losses.

Yet, our findings indicate that the drying substrates can significantly influence the rate of ammonia gas transfer. First, the material properties of the substrate can affect the molecular diffusion of ammonia. For instance, we often observed urine pooling over the surface of pure $\mathrm{MgO}$ because of its low solubility. However, the pooling of urine was either seldom or not observed when $\mathrm{MgO}$ was mixed with biochar and/or bran; both cosubstrates have high water absorption capacities Supplementary Figure S2. It is possible that the presence of co-substrates limited the rate of molecular diffusion of $\mathrm{NH}_{3(\mathrm{aq})}$, and therefore its transfer to the gas phase. Secondly, the drying substrate can prevent $\mathrm{N}$ loss by precipitating $\mathrm{NH}_{4}^{+}$as struvite or magnesium ammonium phosphate $\left(\mathrm{NH}_{4} \mathrm{MgPO}_{4} \cdot 6 \mathrm{H}_{2} \mathrm{O}\right)$, as this irreversibly shifts the ammonia equilibrium away from gaseous ammonia. A simulation of the speciation of the chemical compounds present in urine at thermodynamic equilibrium revealed that, at $50^{\circ} \mathrm{C}, 1.74 \mathrm{~g} \mathrm{MgO} \mathrm{L}^{-1}$ was needed to create a saturated urine solution (Figure 1A). At this condition, if there was no drying, it was possible to form around $4.5 \mathrm{~g}$ struvite $\mathrm{L}^{-1}$. This suggests that at least $15 \%$ of the $\mathrm{NH}_{4}-\mathrm{N}$ (or about $4 \%$ of the total-N) from this study's urine could be captured as struvite.

The average ratio of $\mathrm{Mg}: \mathrm{NH}_{4}: \mathrm{PO}_{4}$ in urine was 1:0.5:2.8 whereas, in theory, a ratio of 1:1:1 is needed to form struvite (Ronteltap et al., 2007). In freshly excreted urine, $\mathrm{Mg}^{2+}$ is present in low concentration (Jönsson et al., 1997), which limits the selfprecipitation of $\mathrm{P}$ as struvite. All the drying substrates used in this study contained $\mathrm{MgO}$, which on hydration provided $\mathrm{Mg}^{2+}$; the $\mathrm{Mg}: \mathrm{PO}_{4}$ ratio varied between $2.2: 1$ (at $50^{\circ} \mathrm{C}$ ) and $2.5: 1$ (at $20^{\circ} \mathrm{C}$ ). Hence, the $\mathrm{N}$ capture as struvite was limited by $\mathrm{PO}_{4}^{3-}$ and not $\mathrm{Mg}^{2+}$. However, in freshly excreted urine, the ammonia $\mathrm{N}$ concentration is normally lower $\left[380 \pm 100 \mathrm{mg}_{\mathrm{N}} \mathrm{L}^{-1}\right.$ according to Randall et al. (2016)] than what was measured in the present study. We therefore modeled the chemical speciation again assuming that urine contained only $400 \mathrm{mg}_{\mathrm{NH}_{4}-\mathrm{N}} \mathrm{L}^{-1}$ (Figure 1B). Lowering the ammonia $\mathrm{N}$ concentration reduces the $\mathrm{MgO}$ solubility (Figure 1A), meaning less $\mathrm{MgO}$ is required to 
saturate urine. Secondly, the $\mathrm{pH}$ of saturated urine is higher-at $30^{\circ} \mathrm{C}$, the $\mathrm{pH}$ is 10.5 (Figure $1 \mathbf{B}$ ). A higher $\mathrm{pH}$ could provide a safety margin and ensure that urease remains inactive during treatment. Thirdly, the amount of struvite formed does not significantly differ (Figure 1C; in fact, struvite could capture $60 \%$ of the ammonia $\mathrm{N}$ in urine).

\section{Study Implications and Limitations}

In this study, we reduced $>90 \%$ of the mass of human urine by dehydrating it in alkaline substrates containing different amounts of $\mathrm{MgO}$. Overall, we were able to treat $37 \mathrm{~L}$ urine $\mathrm{kg}^{-1}$ substrate. This suggests that $<15 \mathrm{~kg}$ of drying substrate is needed to treat the urine excreted by an average person in a year [550 kg according to Vinnerås et al. (2006)] and to yield $40-54 \mathrm{~kg}$ end-product $\mathrm{cap}^{-1} \mathrm{y}^{-1}$. Therefore, drying urine has the potential to improve the logistics surrounding urine recycling since the alternative is to store, transport and apply large volumes of liquid urine as fertilizer (Johansson et al., 2001). The dried urine products can find use as crop fertilizer as they contain $7.8 \% \mathrm{~N}, 0.4 \% \mathrm{P}$, and $3.9 \% \mathrm{~K}$. It may be possible to improve the fertilizer value of the products by drying more urine within the same substrate, since the $\mathrm{pH}$ of the substrate was still $\geq 10$.

Our primary focus in this study was to investigate the use of $\mathrm{MgO}$ to alkalize and dehydrate human urine. We found that $<2 \mathrm{~g}$ $\mathrm{MgO} \mathrm{L}^{-1}$ is required to saturate urine and increase its $\mathrm{pH}$ to about 10 , which is sufficient alkalinity to inactivate urease enzymes, according to Geinzer (2017). We also observed that the alkalinity of all the substrates was preserved despite dehydrating urine added to them. While our study did not explore the maximum urine volume that can be treated before the substrate $\mathrm{pH}$ decreased to $<10$, we found that at least $150 \mathrm{~L}$ of urine can be treated using $1 \mathrm{~kg} \mathrm{MgO}$. This translates to an $\mathrm{MgO}$ requirement of only $3.6 \mathrm{~kg} \mathrm{cap}^{-1} \mathrm{y}^{-1}$ and an annual cost of US $\$ 1.1 \mathrm{cap}^{-1} \mathrm{y}^{-1}$. The world's $\mathrm{Mg}$ reserves are virtually unlimited and the bulk price of MgO is very low (US\$ $0.3 \mathrm{~kg}^{-1}$ ) (Bray and Ghalayin, 2020). We therefore find $\mathrm{MgO}$ to be a very promising substrate for performing alkaline urine dehydration.

There were two limitations in our study. First, we did not expect the urine we used in our experiments to be partially hydrolyzed during the collection. The technology, alkaline urine dehydration, is designed to treat freshly excreted urine. Secondly, on modeling the chemical speciation, we found out that $\mathrm{MgO}$ displayed inverse solubility, i.e., its solubility in urine decreased with temperature (Figure 1A). Therefore, at $20^{\circ} \mathrm{C}$, adding the urine we used in our study to $\mathrm{MgO}$ resulted in a saturation $\mathrm{pH}$ of 9.8 , but increasing its temperature to $50^{\circ} \mathrm{C}$ during the dehydration treatment decreased the $\mathrm{pH}$ to 8.8 . Even if the urine was not partially hydrolyzed, as was the case in our experiments, increasing its temperature to $>40^{\circ} \mathrm{C}$ would decrease the saturation $\mathrm{pH}$ to $<10$. This would increase the risk for reactivation of urease, since alkalizing urine with $\mathrm{MgO}$ to a $\mathrm{pH}$ just above 10 only inactivates the enzyme reversibly. Maintaining a high $\mathrm{pH}$ is more important than the potential benefit of having a higher dehydration rate at high temperatures. Therefore, based on results we obtained from our experiment and from the chemical modeling, we tentatively recommend that urine should be dehydrated at temperature below $40^{\circ} \mathrm{C}$ if it is alkalized using $\mathrm{MgO}$ in order to limit the loss of urea to enzymatic hydrolysis.

Due to the presence of active urease enzymes, the urine used in this study had high initial ammonia $\mathrm{N}$ concentration, about $30 \%$ of the total $\mathrm{N}$. However, under the dehydration treatment conditions $\left(\mathrm{pH} 10\right.$ and $50^{\circ} \mathrm{C}$ ), $>80 \%$ of the ammonia was in the form of $\mathrm{NH}_{3(\mathrm{aq})}$ which could not be recovered. Thus, at least $24 \%$ of the $\mathrm{N}$ loss was attributed to ammonia stripping. Chemical speciation modeling showed that only $4 \%$ of the $\mathrm{N}$ could be recovered as precipitated struvite, suggesting that the $\mathrm{N}$ loss as $\mathrm{NH}_{3(\mathrm{~g})}$ was much higher. For instance, in pure $\mathrm{MgO}$, the $\mathrm{N}$ loss was $33 \%$, of which only $1.2 \%$ of the $\mathrm{N}$ was lost due to chemical hydrolysis of urea. Therefore, to maximise the $\mathrm{N}$ recovery during alkaline dehydration, it is essential to collect and alkalize fresh urine to $\mathrm{pH}>10$ in short time periods. For practical implementation of the technology, this means that dehydration has to take place next to the toilet as this reduces the likelihood of urea hydrolyzing because of the enzymatic activity of microbial biofilms, which are invariably present in the pipe network. Nonetheless, two options exist if urine has to be transported by pipe. First, urine can be pre-treated to prevent urea hydrolysis, e.g., by ion exchange (Simha et al., 2018) or by adding alkalising agents on-site (Chipako and Randall, 2020). Second, the drying substrate can be tailored to capture $\mathrm{NH}_{4}^{+}$. Here, struvite precipitation can be one option but the extent of $\mathrm{N}$ capture depends on the treatment conditions. Our findings indicated that the addition of co-substrates as well as dehydrating urine at temperatures below $40^{\circ} \mathrm{C}$ could limit $\mathrm{NH}_{3}$ volatilization.

\section{CONCLUSION}

This study explored the use of $\mathrm{MgO}$ for treating human urine. We found $\mathrm{MgO}$ to be an effective alkalizing agent, as $<2 \mathrm{~g} \cdot \mathrm{L}^{-1}$ was required to saturate urine and increase its $\mathrm{pH}$ from $<7$ to around 10. However, we also demonstrated that $\mathrm{MgO}$ displayed inverse solubility in urine, and that at temperatures $>40{ }^{\circ} \mathrm{C}$, its saturation $\mathrm{pH}$ decreased $<10$, which increased the risk for reactivation of urease. We also demonstrated that $\mathrm{MgO}$ could be used for treating urine by alkaline dehydration. At a drying temperature of $50^{\circ} \mathrm{C}$, we recovered up to $80 \%$ of the $\mathrm{N}$ from urine by using an alkaline substrate that comprised of $\mathrm{MgO}$ mixed with biochar and wheat bran. The products obtained by dehydrating urine had high concentrations of macronutrients $(7.8 \% \mathrm{~N}, 0.7 \% \mathrm{P}$, and $3.9 \% \mathrm{~K})$ and can find use as crop fertilizers. Our study also demonstrated that in addition to urea hydrolysis, $\mathrm{N}$ from urine could be lost during alkaline dehydration due to ammonia stripping, especially if urine is partially hydrolyzed, either during storage or during dehydration and thus, has high ammonia $\mathrm{N}$ concentration. Therefore, based on experimental observations and preliminary modeling results, we recommended treatment conditions that can minimise the loss of $\mathrm{N}$ as $\mathrm{NH}_{3}$.

\section{DATA AVAILABILITY STATEMENT}

The raw data supporting the conclusions of this article will be made available by the authors, without undue reservation. 


\section{AUTHOR CONTRIBUTIONS}

PS, BV, and CF conceptualized the study and designed the experiments. CF and PS performed the experiments, the physicochemical analyses, and the formal data analysis. DGR modeled the chemical speciation of urine using OLI. BV supervised the study, provided resources and acquired funding. PS wrote the first draft of the manuscript. All authors contributed to manuscript revision, read and approved the submitted version.

\section{FUNDING}

Research presented in this study was financed by grants from the Swedish Research Council, "Productive on-site sanitation system: new value chain for urine based fertilizer" (Grant Number 2015-

\section{REFERENCES}

Başakçilardan-Kabakci, S., İpekoğlu, A. N., and Talinli, I. (2007). Recovery of ammonia from human urine by stripping and absorption. Environ. Eng. Sci. 24 (5), 615-624. doi:10.1089/ees.2006.0412

Blakeley, R. L., Treston, A., Andrews, R. K., and Zerner, B. (1982). Nickel (II)promoted ethanolysis and hydrolysis of $\mathrm{N}$-(2-Pyridylmethyl) urea. A model for urease. J. Am. Chem. Soc. 104 (2), 612-614. doi:10.1021/ja00366a040

Blakeley, R. L., and Zerner, B. (1984). Jack bean urease: the first nickel enzyme. J. Mol. Catal. 23 (2-3), 263-292. doi:10.1016/0304-5102(84)80014-0

Bray, E. L., and Ghalayin, Z. T. (2020). 2017 minerals yearbook magnesium compounds. VA, Virginia: U.S. Department of the Interior and U.S. Geological Survey.

Chipako, T. L., and Randall, D. G. (2020). Urine treatment technologies and the importance of pH. J. Environ. Chem. Eng. 8 (1), 103622. doi:10.1016/j.jece.2019. 103622

Dampney, P. M. R., Basford, W., Goodlass, G., Miller, P., and Richards, I. (2003). Report for Defra Project NT2601. Production and use of nitrogen fertilizers (Accessed June, 2003).

de Mendiburu, F. (2020). Statistical procedures for agricultural research. 2nd Edn. NJ, New Jersey: Wiley.

Dutta, S., and Vinnerås, B. (2016). Fertilizer from dried human urine added to ash and lime-a potential product from eco-sanitation system. Water Sci. Technol. 74 (6), 1436-1445. doi:10.2166/wst.2016.324

Etter, B., Tilley, E., Khadka, R., and Udert, K. M. (2011). Low-cost struvite production using source-separated urine in Nepal. Water Res. 45 (2), 852-862. doi:10.1016/j.watres.2010.10.007

Flanagan, C. P., and Randall, D. G. (2018). Development of a novel nutrient recovery urinal for on-site fertilizer production. J. Environ. Chem. Eng. 6 (5), 6344-6350. doi:10.1016/j.jece.2018.09.060

Fox, J., and Weisberg, S. (2018). An R companion to applied regression. Los Angeles, London: Sage Publications.

Ganrot, Z., Dave, G., and Nilsson, E. (2007). Recovery of N and P from human urine by freezing, struvite precipitation and adsorption to zeolite and active carbon. Bioresour. Technol. 98 (16), 3112-3121. doi:10.1016/j.biortech.2006. 10.038

Geinzer, M. (2017). Inactivation of the urease enzyme by heat and alkaline $\mathrm{pH}$ treatment. Master's thesis. Uppsala, Sweden: Swedish University of Agricultural Sciences.

Harder, R., Wielemaker, R., Larsen, T. A., Zeeman, G., and Öberg, G. (2019). Recycling nutrients contained in human excreta to agriculture: pathways, processes, and products. Crit. Rev. Environ. Sci. Technol. 49 (8), 695-743. doi:10.1080/10643389.2018.1558889

Huang, J.-C., and Shang, C. (2006). Advanced physicochemical treatment processes-air stripping. London, United Kingdom: IWA.
03072) and "UDT 2.0-Urine Dehydration Technology for Sanitation 2.0" (Grant Number 2018-05023). DG Randall was supported through the FLAIR Fellowship by the Royal Society and the African Academy of Sciences.

\section{ACKNOWLEDGMENTS}

Sven Smårs helped build the experimental setup. Colleagues at SLU are thanked for donating urine.

\section{SUPPLEMENTARY MATERIAL}

The Supplementary Material for this article can be found online at: https://www.frontiersin.org/articles/10.3389/fenvs.2020.619901/ full\#supplementary-material.

Johansson, M., Jönsson, H., Höglund, C., Richert Stintzing, A., and Rodhe, L. (2001). Urine separation-closing the nutrient cycle. Final report on the R\&D project source-separated human urine-a future source of fertilizer for agriculture in the Stockholm region. Stockholm, Sweden: Stockholm Water Company.

Jönsson, H., Stenström, T. A., Svensson, J., and Sundin, A. (1997). Source separated urine-nutrient and heavy metal content, water saving and faecal contamination. Water Sci. Technol. 35 (9), 145-152.

Kirchmann, H., and Pettersson, S. (1994). Human urine-chemical composition and fertilizer use efficiency. Fert. Res. 40 (2), 149-154. doi:10.1007/ BF00750100

Krajewska, B. (2009). Ureases I. Functional, catalytic and kinetic properties: a review. J. Mol. Catal. B Enzym. 59 (1-3), 9-21. doi:10.1016/j.molcatb.2009. 01.003

Larsen, T. A., Udert, K. M., and Lienert, J. (2013). Source separation and decentralization for wastewater management. London, United Kingdom: IWA Publishing.

Martin, T. M. P., Esculier, F., Levavasseur, F., and Houot, S. (2020). Human urinebased fertilizers: a review. Crit. Rev. Environ. Sci. Technol. 1-47. doi:10.1080/ 10643389.2020.1838214

Mobley, H. L., and Hausinger, R. P. (1989). Microbial ureases: significance, regulation, and molecular characterization. Microbiol. Rev. 53 (1), $85-108$.

OLI Systems Inc. (2020). OLI stream analyser, NJ, New Jersey: OLI Systems.

Randall, D. G., Krähenbühl, M., Köpping, I., Larsen, T. A., and Udert, K. M. (2016). A novel approach for stabilizing fresh urine by calcium hydroxide addition. Water Res. 95, 361-369. doi:10.1016/j.watres.2016.03.007

Rocha, S. D. F., Mansur, M. B., and Ciminelli, V. S. T. (2004). Kinetics and mechanistic analysis of caustic magnesia hydration. J. Appl. Chem. Biotechnol. 79 (8), 816-821. doi:10.1002/jctb.1038

Ronteltap, M., Maurer, M., and Gujer, W. (2007). Struvite precipitation thermodynamics in source-separated urine. Water Res. 41 (5), 977-984. doi:10.1016/j.watres.2006.11.046

RStudio Team (2016). RStudio: integrated development for R. Boston, MA: RStudio.

Senecal, J., Nordin, A., Simha, P., and Vinnerås, B. (2018). Hygiene aspect of treating human urine by alkaline dehydration. Water Res. 144, 474-481. doi:10. 1016/j.watres.2018.07.030

Senecal, J., and Vinnerås, B. (2017). Urea stabilisation and concentration for urinediverting dry toilets: urine dehydration in ash. Sci. Total Environ. 586, 650-657. doi:10.1016/j.scitotenv.2017.02.038

Simha, P., Senecal, J., Nordin, A., Lalander, C., and Vinnerås, B. (2018). Alkaline dehydration of anion-exchanged human urine: volume reduction, nutrient recovery and process optimisation. Water Res. 142, 325-336. doi:10.1016/j. watres.2018.06.001

Simha, P., Deb, C. K., Randall, D. G., and Vinnerås, B. (in preparation). Solubility curves for $\mathrm{MgO}$ and $\mathrm{Mg}(\mathrm{OH}) 2$ in fresh urine. Bethesda, Maryland: NCBI. 
Simha, P., Karlsson, C., Viskari, E.-L., Malila, R., and Vinnerås, B. (2020a). Field testing a pilot-scale system for alkaline dehydration of source-separated human urine: a case study in Finland. Front. Environ. Sci. 8, 570637. doi:10.3389/fenvs.2020.570637

Simha, P., Lalander, C., Nordin, A., and Vinnerås, B. (2020b). Alkaline dehydration of source-separated fresh human urine: preliminary insights into using different dehydration temperature and substrate. Sci. Total Environ. 733, 139313. doi:10. 1016/j.scitotenv.2020.139313

Simha, P., Senecal, J., Gustavsson, D. J. I., and Vinnerås, B. (2020c). "Resource recovery from wastewater: a new approach with alkaline dehydration of urine at source," in Current developments in biotechnology and bioengineering: sustainable bioresources for emerging bioeconomy, Editors A. Pandey, R. Kataki, D. Pant, and S. Khanal (Netherlands: Elsevier Publications).

Tettenborn, F., Behrendt, J., and Otterpohl, R. (2007). Final Report. Resource recovery and removal of pharmaceutical residues-treatment of separate collected urine (Accessed March, 2017).

Udert, K. M., Larsen, T. A., Biebow, M., and Gujer, W. (2003). Urea hydrolysis and precipitation dynamics in a urine-collecting system. Water Res. 37 (11), 2571-2582. doi:10.1016/s0043-1354(03)00065-4

Vinnerås, B., Palmquist, H., Balmér, P., and Jönsson, H. (2006). The characteristics of household wastewater and biodegradable solid waste-a proposal for new
Swedish design values. Urban Water J. 3 (1), 3-11. doi:10.1080/ 15730620600578629

Warner, R. C. (1942). The kinetics of the hydrolysis of urea and of arginine. J. Biol. Chem. 142 (2), 705-723.

Wilsenach, J. A., Schuurbiers, C. A., and van Loosdrecht, M. C. (2007). Phosphate and potassium recovery from source separated urine through struvite precipitation. Water Res. 41 (2), 458-466. doi:10.1016/j.watres. 2006.10 .014

Conflict of Interest: The authors declare that the research was conducted in the absence of any commercial or financial relationships that could be construed as a potential conflict of interest.

Copyright (c) 2021 Simha, Friedrich, Randall and Vinnerås. This is an open-access article distributed under the terms of the Creative Commons Attribution License (CC $B Y$ ). The use, distribution or reproduction in other forums is permitted, provided the original author(s) and the copyright owner(s) are credited and that the original publication in this journal is cited, in accordance with accepted academic practice. No use, distribution or reproduction is permitted which does not comply with these terms. 